\title{
Profiling $B$ and $T$ cell immune responses to co-infection of Mycobacterium tuberculosis and hookworm in humans
}

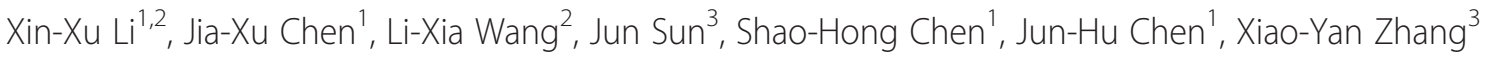
and Xiao-Nong Zhou ${ }^{1 *}$

\begin{abstract}
Background: Humoral and cellular immune responses play protective roles against Mycobacterium tuberculosis (MTB) infection. However, hookworm infection decreases the immune response to hookworm and bystander antigens. Currently, immune responses to co-infection of MTB and hookworm are still unknown, although co-infection has been one of the public health problems in co-endemic areas of pulmonary tuberculosis (PTB) and hookworm disease. Therefore, it is essential to evaluate B and T cell immune responses to the co-infection.

Methods: Seventeen PTB cases co-infected with hookworm, 26 PTB cases, 15 patients with hookworm infection, and 24 healthy controls without PTB or hookworm infection were enrolled in the study. Expressions of CD3, CD4, CD8, CD10, CD19, CD20, CD21, CD25, CD27, CD38, FoxP3, and PD-1 were assessed on B and T cell subsets using multicolor flow cytometry.

Results: For the B cell $\left(\mathrm{CD} 19^{+}\right)$subsets, naïve $\mathrm{B}$ cells $\left(\mathrm{CD} 10^{-} \mathrm{CD} 27^{-} \mathrm{CD} 21^{+} \mathrm{CD} 20^{+}\right)$, plasma cells $\left(\mathrm{CD} 10^{-} \mathrm{CD} 27^{+} \mathrm{CD} 21\right.$ $\left.{ }^{-} \mathrm{CD} 20^{-}\right)$, and tissue-like memory B cells $\left(\mathrm{CD} 10^{-} \mathrm{CD} 27^{-} \mathrm{CD} 21^{-} \mathrm{CD} 2 \mathrm{O}^{+}\right)$had higher proportions, whilst resting memory $\mathrm{B}$ cells $\left(\mathrm{CD} 10^{-} \mathrm{CD} 27^{+} \mathrm{CD} 21^{+} \mathrm{CD} 2 \mathrm{O}^{+}\right)$had lower proportions in the group co-infected with MTB and hookworm as compared to other groups. Frequencies of activated memory B cells $\left(\mathrm{CD} 10^{-} \mathrm{CD} 27^{+} \mathrm{CD} 21^{-} \mathrm{CD} 20^{+}\right)$did not differ among the four groups. For the T cell $\left(\mathrm{CD}^{+}\right)$subsets, frequencies of regulatory $T$ cells $\left(C D 4^{+} \mathrm{CD}_{2} 5^{+} \mathrm{Foxp} 3^{+}\right)$and exhausted $\mathrm{CD}^{+}$and $\mathrm{CD} 8^{+}$T cells $\left(\mathrm{CD} 4^{+} \mathrm{PD}-1^{+}\right.$and $\left.\mathrm{CD} 8^{+} \mathrm{PD}-1^{+}\right)$were higher, and frequencies of activated $\mathrm{CD} 4^{+}$and $\mathrm{CD} 8^{+} \mathrm{T}$ cells $\left(\mathrm{CD} 4^{+} \mathrm{CD} 38^{+}\right.$and $\left.\mathrm{CD} 8^{+} \mathrm{CD} 38^{+}\right)$were lower in the co-infected group as compared to the other groups.

Conclusion: The change patterns of the cell profile of circulating lymphocytes were indentified in human co-infection of MTB and hookworm, which might indicate that the humoral and cellular immune responses are more suppressed.
\end{abstract}

Keywords: Co-infection, Mycobacterium tuberculosis, Hookworm, Immune response

\section{Multilingual abstracts}

Please see Additional file 1 for translations of the abstract into the six official working languages of the United Nations.

\section{Background}

Tuberculosis (TB) and hookworm infection are among the most important public health problems worldwide.

\footnotetext{
*Correspondence: xiaonongzhou1962@gmail.com

'National Institute of Parasitic Diseases, Chinese Center for Disease Control and Prevention, Key Laboratory of Parasite and Vector Biology, Ministry of Health, WHO Collaborating Centre for Malaria, Schistosomiasis and Filariasis, 207 Rui Jin Er Road, Huangpu District, Shanghai 200025, PR China (PRC) Full list of author information is available at the end of the article
}

In 2011, there were an estimated 8.7 million new TB cases and 1.4 million people died from the disease globally, with the burden of TB geographically highest in Asia and Africa [1]. The World Health Organization (WHO) also reported that hookworm infection afflicted an estimated 740 million people in the developing nations of the tropics in 2003, and the largest numbers of cases occurred in impoverished rural areas of Sub-Saharan Africa, Latin America, Southeast Asia, and China [2]. In addition to being two independent major health problems, the observed associations between TB and hookworm infection are important, although there have been little related studies conducted worldwide [3]. For example, the 
prevalence of hookworm infection among TB cases was about $6 \%-11 \%$, while TB prevalence among patients with hookworm infection was near $17 \%$ in some East African countries [4-6]. Therefore, it is essential to profile the human co-infection of Mycobacterium tuberculosis (MTB) and hookworm.

MTB is a facultative intracellular pathogen. The effective cell-mediated immune response to MTB infection, involving mainly the $\mathrm{CD}^{+}$and $\mathrm{CD}^{+} \mathrm{T}$ cell subsets, plays an essential role in the pathogenesis of $\mathrm{TB}[7,8]$. Despite this, emerging evidence suggests that B cells and humoral immunity can also modulate the immune response to MTB infection $[9,10]$. Unlike MTB infection, which is phagocytosed by resident alveolar macrophages and tissue dendritic cells in the lung and replicates inside these cells [11], hookworm infection presents the host with an extensive diversity of antigenic challenges, immune stimulation, and immune modulation (including humoral and cellular responses) during various stages, from skin invasion, to transit through lung tissues, to arrival in the gut and penetration of its mucosa [12]. Many studies have confirmed that hookworm infection decreases the ability of the immune system to respond to hookworm and bystander antigens, as evidenced by decreased lymphocyte responses in hookworm-infected humans [13-15]. However, the immune system response to co-infection of MTB and hookworm in humans has still not been clarified.

In order to evaluate $\mathrm{B}$ and $\mathrm{T}$ cell immune responses to co-infection of MTB and hookworm, this study compared alterations of $\mathrm{B}$ and $\mathrm{T}$ cell subsets, expressions of whose markers were analyzed by flow cytometry [16] in pulmonary TB (PTB) cases with and without hookworm infection, patients only with hookworm infection, and healthy controls without PTB or hookworm infection.

\section{Methods}

\section{Study population}

The study was conducted in Gushi County of Henan province, which is an agricultural county that lies in the center of China. The study was conducted between July and September 2012 [17]. Seventeen PTB cases coinfected with hookworm (TB $+\mathrm{HW}$ group), 26 РTB cases without hookworm infection (TB group), 15 patients only with hookworm infection (HW group), and 24 healthy controls without PTB or hookworm infection (HC group) were enrolled in the study. All PTB cases were selected from the TB surveillance system, diagnosed according to the diagnostic criteria of the National Tuberculosis Program (criteria includes three sputum smear examinations, chest imaging, and clinical symptoms) [18]. Two stool specimens were collected for the diagnosis of the hookworm infection and three smears of each stool specimen were examined by the modified Kato-Katz thick smear technique (a semi-quantitative stool examination technique for detection of helminthic ova) [19]. The egg count for hookworm was not assessed. Apart from hookworm, there were no other helminth infections in participants. No participant received any anti-parasitic treatment against hookworm before blood collection. There were no statistical differences between the ages of the participants from all four groups: TB + HW (median age 60 years), TB (median age 61 years), HW (median age 65 years), and $\mathrm{HC}$ (median age 62 years). All PTB cases received anti-TB treatment as PTB cases are treated immediately once they are diagnosed based on the national guidelines in China. The main regimen of anti-MTB treatment is the combination of isoniazid, rifampicin, pyrazinamide, ethambutol, and streptomycin, or their derivatives [18]. The duration of anti-TB treatment was similar between the TB + HW group (median 4.5 months) and the TB group (median 4.4 months) (see Table 1). General medical checkups confirmed that participants had no organic or immune system diseases. Participants from the $\mathrm{HW}$ and $\mathrm{HC}$ groups were confirmed non-TB by sputum smear examination. All participants were HIV negative.

\section{Ethical statement}

The study was evaluated and approved by the Ethics Review Committee of the National Institute of Parasitic Diseases, Chinese Center for Disease Control and Prevention. All participants gave their written informed consents prior to the study commencing. At the completion of the study, anti-parasitic treatment was offered at no charge to all participants with positive hookworm infection, in accordance with the local treatment guidelines.

\section{Cells preparation}

EDTA-treated whole blood was obtained from all participants and sent to the Key Laboratory of Medical

Table 1 Characteristics of study participants [Median (IQR)]

\begin{tabular}{|c|c|c|c|c|c|}
\hline \multirow[t]{2}{*}{ Group } & \multirow[t]{2}{*}{$\mathbf{N}$} & \multicolumn{2}{|c|}{ Sex (n) } & \multirow{2}{*}{$\begin{array}{l}\text { Age } \\
\text { (years) }\end{array}$} & \multirow{2}{*}{$\begin{array}{l}\text { Duration } \\
\text { of anti-TB } \\
\text { treatment } \\
\text { (months) }\end{array}$} \\
\hline & & Male & Female & & \\
\hline $\mathrm{HC}$ & 24 & 14 & 10 & $62(48-70)$ & NA \\
\hline HW & 15 & 10 & 5 & $65(56-70)$ & NA \\
\hline $\mathrm{TB}$ & 26 & 15 & 11 & $61(44-67)$ & $4.4(2.5-5.3)$ \\
\hline $\mathrm{TB}+\mathrm{HW}$ & 17 & 9 & 8 & $60(50-72)$ & $4.5(3.0-5.4)$ \\
\hline
\end{tabular}

IQR: interquartile range; HC: healthy controls without PTB or hookworm infection; HW: patients only with hookworm infection; TB: PTB cases without hookworm infection; TB + HW: PTB cases co-infected with hookworm; NA: not applicable. 
Molecular Virology of Ministry of Education, Institutes of Biomedical Sciences, Fudan University (Shanghai, China) within eight hours. Peripheral blood mononuclear cells (PBMCs) were isolated from EDTAtreated whole blood by Ficoll-Hypaque (Sigma Chemical Co., St Louis, MO, USA) density gradient centrifugation.

\section{Flow cytometric analysis}

The freshly isolated PBMCs were washed with phosphate-buffered saline (PBS)-2\% fetal bovine serum and stained with surface antibodies (CD19-FITC, CD10PE, CD20-PerCP-Cy5-5, CD21-APC, CD27-PE-Cy7, CD3-FITC, CD4-PE-Cy7, CD8-Pacific Blue, CD25-PE, FoxP3-APC, CD38-APC-Cy7, PD-1-PerCP-Cy5-5) for 30 minutes at $4^{\circ} \mathrm{C}$ in the dark. The clones used for each antibody were HIB19, eBioCB-CALLA, IH7, HB5, 0323, OKT3, SK3, SK1, BC96, PCH101, HIT2, and EBioJ105, respectively (see Table 2). Cells were then washed, fixed, and permeabilized using the Foxp3/Transcription Factor Staining Buffer Set kit (eBioscience, San Diego, CA, USA), according to its instructions. Following fixation, the cells were washed twice in the perm buffer and incubated for 30 minutes at $4^{\circ} \mathrm{C}$, with anti-human Foxp3 antibodies conjugated to allophycocyanin (APC). Following staining, the cells were washed, fixed (PBS containing $1 \%$ paraformaldehyde), and stored at $4^{\circ} \mathrm{C}$ until analysis (within 24 hours) in a modified FACSAria ${ }^{\text {тм }}$ flow cytometer (BD Immunocytometry Systems, BD Bioscience, San Jose, CA, USA). All surface antibodies were purchased from eBioscience (San Diego, CA, USA). Data acquisition and analysis was performed using the BD FACSDiva $^{\mathrm{Tm}}$ software (BD Bioscience, San Jose, CA, USA).

Table 2 Antibodies used for flow cytometry

\begin{tabular}{lll}
\hline Antigen & Clone & Color \\
\hline CD3 & OKT3 & FITC \\
CD4 & SK3 & PE-Cy7 \\
CD8 & SK1 & Pacific Blue \\
CD10 & eBioCB-CALLA & PE \\
CD19 & HIB19 & FITC \\
CD20 & IH7 & PerCP-Cy5-5 \\
CD21 & HB5 & APC \\
CD25 & BC96 & PE \\
CD27 & 0323 & PE-Cy7 \\
CD38 & HIT2 & APC-Cy7 \\
FoxP3 & PCH101 & APC \\
PD-1 & EBioJ105 & PerCP-Cy5-5 \\
\hline
\end{tabular}

APC: allophycocyanin; FITC: fluorescein isothiocyanate; PE: phycoerythrin PerCP: peridinin chlorophyll protein.

\section{Evaluation of B cell subsets}

Gating strategies were set to evaluate B cell subsets (see Figure 1). Peripheral $\mathrm{B}$ cell is only necessary to gate on $\mathrm{CD}_{19}{ }^{+}$cells that also co-expressed CD20 [20]. CD10 expression defines two populations of $\mathrm{B}$ cell, a minor mature population that co-expresses CD27 and an immature $\mathrm{CD}^{2} 7^{-}$population [21]. Naïve B cells are defined as $\mathrm{CD} 19^{+} \mathrm{CD} 10^{-} \mathrm{CD} 27^{-} \mathrm{CD} 21^{+} \mathrm{CD} 20^{+} \mathrm{B}$ cells, and resting memory $\mathrm{B}$ cells are defined as $\mathrm{CD} 19^{+} \mathrm{CD} 10^{-}$ $\mathrm{CD} 27^{+} \mathrm{CD} 21^{+} \mathrm{CD} 20^{+} \mathrm{B}$ cells [22]. Mature activated memory $\mathrm{B}$ cells are identified by the $\mathrm{B}$ cell surface marker $\mathrm{CD} 19^{+} \mathrm{CD} 10^{-} \mathrm{CD} 27^{+} \mathrm{CD} 21^{-} \mathrm{CD} 20^{+}$, and tissuelike memory $\mathrm{B}$ cells are identified by marker $\mathrm{CD} 19^{+}$ $\mathrm{CD} 10^{-} \mathrm{CD} 27^{-} \mathrm{CD} 21^{-} \mathrm{CD} 20^{+}$[22]. Plasma cells are identified by marker $\mathrm{CD} 19^{+} \mathrm{CD} 10^{-} \mathrm{CD} 27^{+} \mathrm{CD} 21^{-} \mathrm{CD} 20^{-}$[23]. Definitions of $\mathrm{B}$ cell subsets are presented in Table 3.

\section{Evaluation of $\mathrm{T}$ cell subsets}

Gating strategies were set to evaluate T cell subsets (see Figure 2). Peripheral $\mathrm{T}$ cell is necessary to gate on $\mathrm{CD}^{+}$ cells because CD3 conformation is crucial for T cell signaling [24]. It is well known that expression of CD4 or CD8 on $\mathrm{T}$ cells is pivotal in defining them as $\mathrm{T}$ helper or $\mathrm{T}$ cytotoxic cells, respectively. In defining $\mathrm{T}$ cell subsets, we used the following nomenclature: regulatory $\mathrm{T}$ (Treg) cells $\left(\mathrm{CD}^{+} \mathrm{CD}^{+} \mathrm{CD} 5^{+} \mathrm{Foxp}^{+}\right)$[25], activated $\mathrm{CD} 4^{+} \mathrm{T}$ cells $\left(\mathrm{CD}^{+} \mathrm{CD}^{+} \mathrm{CD} 38^{+}\right)$[26], exhausted $\mathrm{CD}^{+} \mathrm{T}$ cells $\left(\mathrm{CD}^{+} \mathrm{CD}^{+} \mathrm{PD}-1^{+}\right)$[27], activated $\mathrm{CD}^{+} \mathrm{T}$ cells $\left(\mathrm{CD}^{+}\right.$ $\left.\mathrm{CD}^{+} \mathrm{CD} 38^{+}\right)$[26], and exhausted $\mathrm{CD}^{+} \mathrm{T}^{-}$cells $\left(\mathrm{CD}^{+} \mathrm{CD} 8^{+}\right.$ PD- $1^{+}$) [27]. Definitions of $\mathrm{T}$ cell subsets are presented in Table 4 .

\section{Statistical analysis}

The immune parameters were measured using the percentage of each subpopulation in their respective populations, such as B cell (\% of lymphocytes), immature B cell (\% of B cell), T cell (\% of lymphocytes), and Treg cell (\% of $\mathrm{CD}^{+} \mathrm{T}$ cell) (see Tables 5 and 6). Characteristics of the study population and the different immune parameters were recorded as median (interquartile range [IQR]). Comparisons between groups were analyzed using the Wilcoxon Rank-Sum test, a non-parametric test. All statistical analyses and graphs were performed using R (Version 3.0.1, The R Foundation for Statistical Computing), a language and environment for statistical computing and graphics. Due to the small samples in this study, all two-tailed $p$-values were considered statistically significant when lower than 0.10 for capturing potential differences as much as possible, as $p$-values with the $\alpha<0.10$ critical value as a threshold perform better for statistical tests of small samples than other $p$-values [28]. 


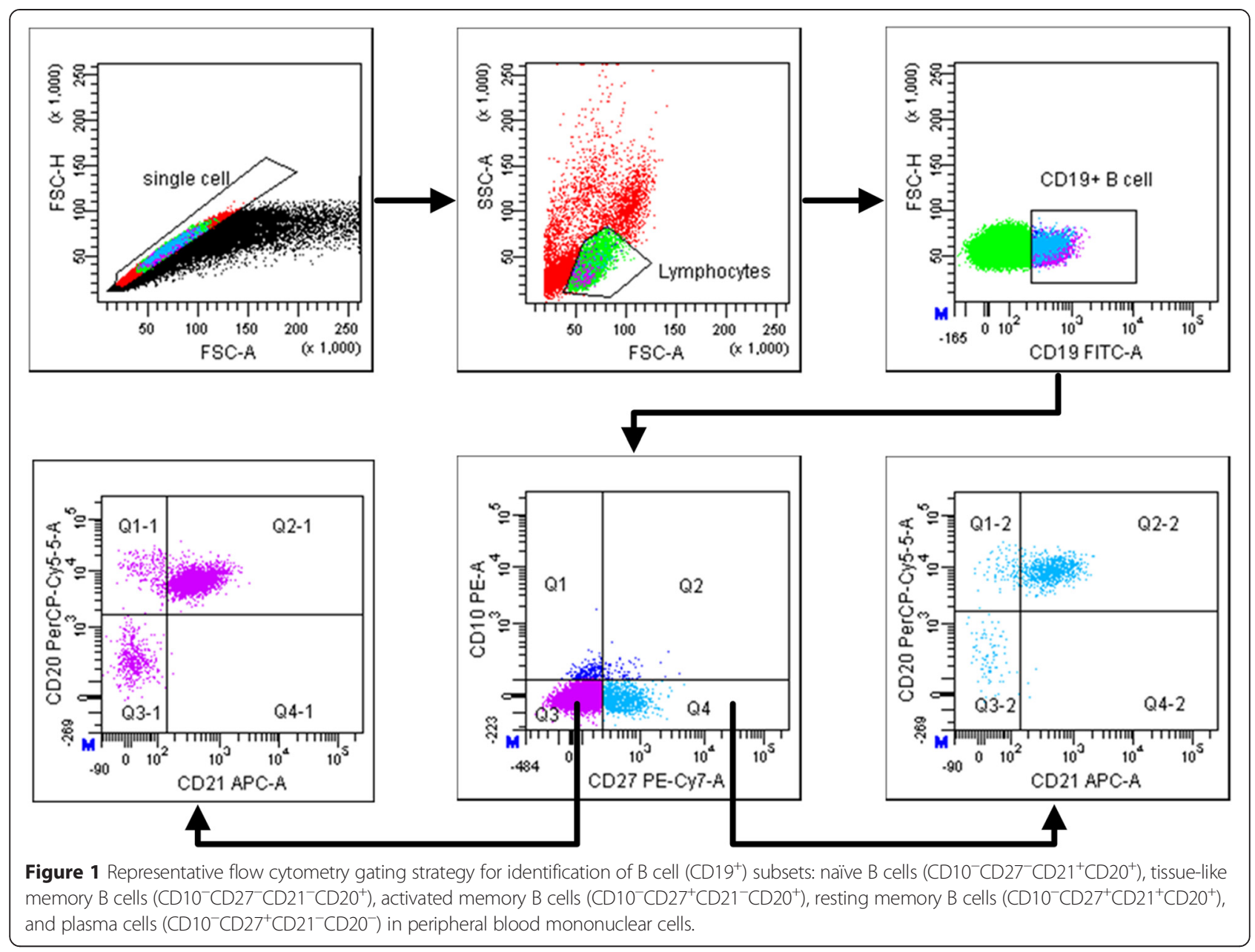

\section{Results}

Alterations of B cell subset in PTB cases with hookworm infection

We analyzed B cell frequencies and B cell subset frequencies to evaluate whether peripheral B cell subset compartment alters among the study groups (see Table 5 and Figure 3). Total percentages of peripheral B cells were similar among the four groups (see Figure 3A). The proportions of naïve $\mathrm{B}$ cells were found to be higher in the TB $+\mathrm{HW}$ group than in the $\mathrm{HC}$ group $(p=0.0646)$

Table 3 Definitions of B cell subsets

\begin{tabular}{ll}
\hline Parameter & Subset \\
\hline $\mathrm{CD} 19^{+}$ & B cell \\
$\mathrm{CD} 19^{+} \mathrm{CD} 10^{+} \mathrm{CD} 27^{-}$ & Immature B cell \\
$\mathrm{CD} 19^{+} \mathrm{CD} 10^{-} \mathrm{CD} 27^{-} \mathrm{CD} 21^{+} \mathrm{CD} 20^{+}$ & Naïve B cell \\
$\mathrm{CD} 19^{+} \mathrm{CD} 10^{-} \mathrm{CD} 27^{-} \mathrm{CD} 21^{-} \mathrm{CD} 20^{+}$ & Tissue-like memory B cell \\
$\mathrm{CD} 19^{+} \mathrm{CD} 10^{-} \mathrm{CD} 27^{+} \mathrm{CD} 21^{-} \mathrm{CD} 20^{+}$ & Activated memory B cell \\
$\mathrm{CD} 19^{+} \mathrm{CD} 10^{-} \mathrm{CD} 27^{+} \mathrm{CD} 21^{+} \mathrm{CD} 20^{+}$ & Resting memory B cell \\
$\mathrm{CD} 19^{+} \mathrm{CD} 10^{-} \mathrm{CD} 27^{+} \mathrm{CD} 21^{-} \mathrm{CD} 20^{-}$ & Plasma cell \\
\hline
\end{tabular}

and TB group $(p=0.0547)$ (see Figure $3 \mathrm{~B})$. Increased proportions of resting memory B cells were observed in the HW group compared with the TB group $(p=0.0465)$ and $\mathrm{TB}+\mathrm{HW}$ group $(p=0.0098)$ (see Figure $3 \mathrm{C})$. The proportions of activated memory B cells were also similar among the four groups (see Figure 3D). The percentages of tissue-like memory $B$ cells were found to be lower in the TB group than in the HC group ( $p=$ $0.0121)$ and TB + HW group $(p=0.0515)$ (see Figure $3 \mathrm{E}$ ), and decreased proportions of plasma cells were observed in the HW group as compared to the TB group ( $p=$ $0.0599)$ and TB + HW group ( $p=0.0127)$ (see Figure $3 \mathrm{~F}$ ).

\section{Alterations of T cell subset in PTB cases with hookworm infection}

We examined $\mathrm{T}$ cell frequencies and $\mathrm{T}$ cell subset frequencies to evaluate whether peripheral $\mathrm{T}$ cell subset compartment alters among the study groups (see Table 6 and Figure 4). Total frequencies of peripheral $\mathrm{T}$ cells were similar among the four groups (see Figure 4A). Higher percentages of Treg cells were detected in the $\mathrm{TB}+\mathrm{HW}$ group than in the HC group $(p=0.0431)$ and 


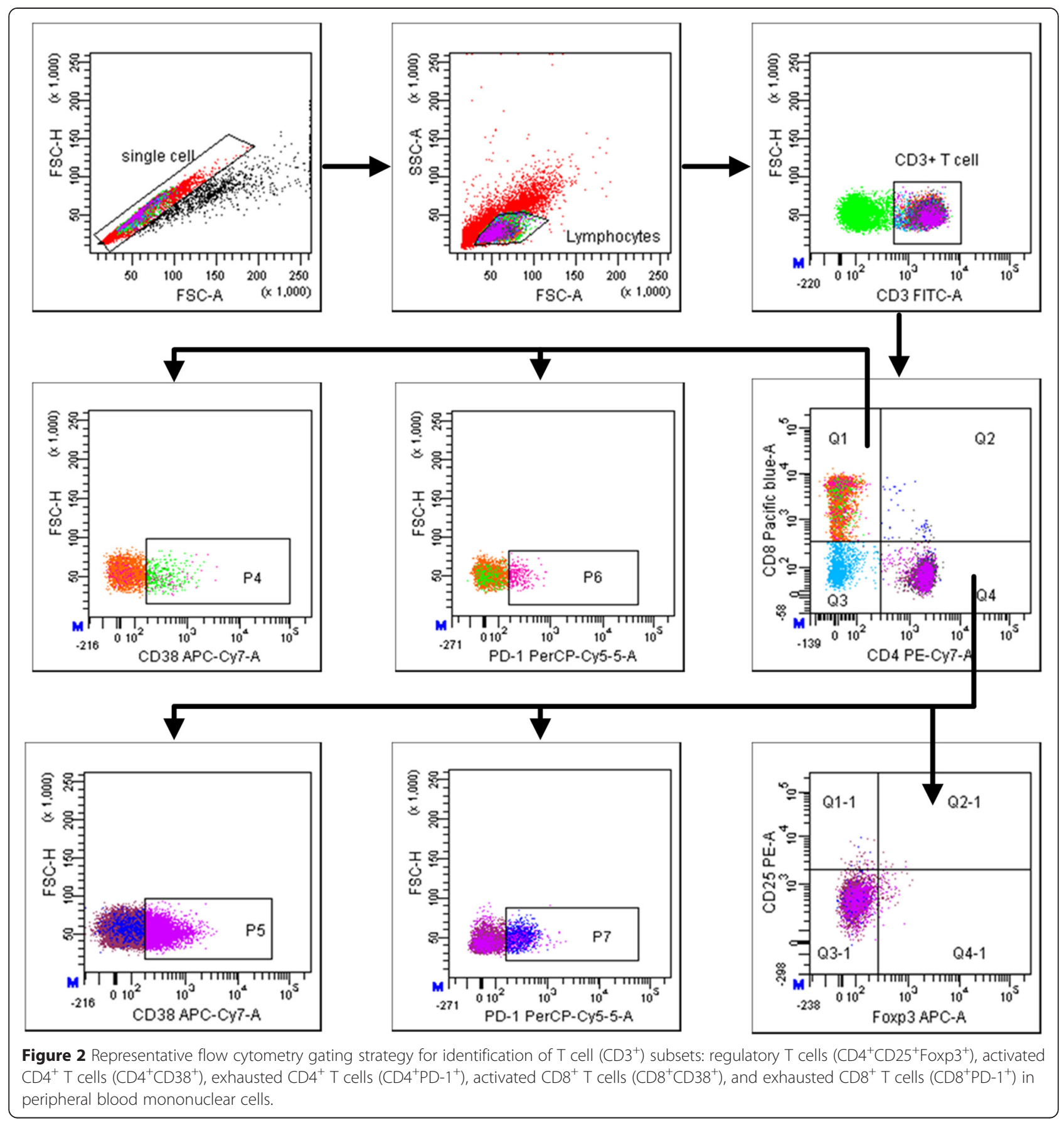

TB group $(p=0.0072)$ (see Figure $4 \mathrm{~B})$. The TB $+\mathrm{HW}$ group showed lower frequencies of activated $C D 4^{+} \mathrm{T}$ cells as compared to the HC group $(p=0.0051)$, HW group ( $p=0.0389)$, and TB group $(p=0.0988)$, while the TB group also showed lower frequencies compared to the HC group $(p=0.0994)$ (see Figure $4 C)$. In contrast, the $\mathrm{TB}+\mathrm{HW}$ group showed higher frequencies of exhausted $\mathrm{CD}^{+} \mathrm{T}$ cells as compared to the $\mathrm{HC}$ group $(p=0.0262)$ and TB group $(p=0.0484)$ (see Figure 4D). The TB $+\mathrm{HW}$ group displayed lower proportions of activated $\mathrm{CD} 8^{+} \mathrm{T}$ cells as compared to the $\mathrm{HC}$ group $(p=$ 0.0462 ) (see Figure 4E). The proportions of exhausted $\mathrm{CD}^{+} \mathrm{T}$ cells were lower in the TB group than in the HW group $(p=0.0528)$ and TB + HW group $(p=0.0359)$ (see Figure $4 \mathrm{~F})$.

\section{Discussion}

Among parasitic infections that regulate or alter host immune responses, helminth infections often lead to systemic immune suppression or anergy [29]. As the 
Table 4 Definitions of $\mathrm{T}$ cell subsets

\begin{tabular}{ll}
\hline Parameter & Subset \\
\hline $\mathrm{CD}^{+}$ & T cell \\
$\mathrm{CD}^{+}{ }^{+} \mathrm{CD} 4^{+}$ & $\mathrm{CD} 4^{+} \mathrm{T}$ cell \\
$\mathrm{CD}^{+} \mathrm{CD}^{+}$ & $\mathrm{CD} 8^{+} \mathrm{T}$ cell \\
$\mathrm{CD}^{+} \mathrm{CD}^{+} \mathrm{CD} 25^{+} \mathrm{Foxp3}^{+}$ & Regulatory $\mathrm{T}$ cell \\
$\mathrm{CD}^{+} \mathrm{CD}^{+} \mathrm{CD} 38^{+}$ & Activated $\mathrm{CD} 4^{+} \mathrm{T}$ cell \\
$\mathrm{CD}^{+} \mathrm{CD}^{+} \mathrm{PD}-1^{+}$ & Exhausted $\mathrm{CD} 4^{+} \mathrm{T}$ cell \\
$\mathrm{CD}^{+} \mathrm{CD}^{+} \mathrm{CD} 38^{+}$ & Activated $\mathrm{CD} 8^{+} \mathrm{T}$ cell \\
$\mathrm{CD}^{+} \mathrm{CD} 8^{+} \mathrm{PD}-1^{+}$ & Exhausted $\mathrm{CD} 8^{+} \mathrm{T}$ cell \\
\hline
\end{tabular}

important and common species of helminth, larval and adult hookworm release stage-specific antigenic molecules that induce antibody responses, eosinophilia, and florid intestinal inflammation via skin invasion, transit through lung tissues, and arrival in the gut and penetration of its mucosa [12]. However, there is no clear evidence that this offers the host any protection by significantly reducing larval and adult hookworm numbers [30]. In contrast, immunosuppression exists in patients with hookworm infection, and helminth infections including hookworm influence host immune responses to bystander antigens. For example, helminth infections are able to influence both the clinical outcome and the immune response of patients with cutaneous leishmaniasis [31]. Moreover, hookworm excretory/secretory products were observed to suppress intestinal pathology in a mouse model of colitis [32]. Up-to-date information on the immune responses to co-infection of MTB and hookworm in humans is unavailable.

Recent studies have suggested that B cells and humoral immunity can modulate host defense against various intracellular pathogens, including MTB, through a variety of interactions with the cellular immune response $[9,10]$. In this study, we found that higher percentages of naïve $B$ cells and plasma cells existed in the TB + HW group compared to the TB or HW groups, although percentages of activated memory $\mathrm{B}$ cells did not differ among the groups. The primary antibody response is mediated by naïve $B$ cells, and memory B cells mediate long-term protective immunity due to their capacity to generate secondary humoral responses [33]. After being activated following the receipt of signals through B-cell receptor, CD40, Tolllike receptor, and cytokine receptors, naive $\mathrm{B}$ cells can enter a germinal center and then differentiate into either high-affinity plasma cells or memory B cells [33]. The results from our study indicated that naïve B cells became activated and then mostly differentiated into plasma cells in settings of co-infection of MTB and hookworm. However, we can hardly educe that the primary antibody response might be increased by MTB infection concurrent with hookworm infection in contrast with the secondary humoral response because boundaries between primary and secondary humoral responses blur for patients with chronic infectious diseases.

Tissue-like memory B cells expressed patterns of homing and inhibitory receptors and proliferated poorly in response to $B$ cell stimuli, in which immunoglobulin diversities and replication histories have been shown to be lower [34]. Findings of this study showed that coinfection of MTB and hookworm increased proportions of tissue-like memory B cells in contrast with MTB infection, which demonstrated that activation of memory $\mathrm{B}$ cells and the humoral response against pathogens might be lower in PTB cases when they are co-infected with hookworm. Resting memory B cells are intrinsically programmed for enhanced survival and responsiveness to diverse stimuli compared to naïve B cells [35]. In this study, we found that co-infection of MTB and hookworm reduced frequencies of resting memory B cells compared to hookworm infection, which was further proof that the humoral response is more suppressed in patients with hookworm when they are co-infected with MTB.

The importance of $\mathrm{CD} 4^{+}$and $\mathrm{CD} 8^{+} \mathrm{T}$ cells for protection against $\mathrm{TB}$ is well known. After antigen presentation by accessory cells, $\mathrm{CD} 4^{+} \mathrm{T}$ cells are activated to produce IFN- $\gamma$, the prototypic Th1 cytokine that enhances the mycobactericidal capacity of macrophages [36,37], and $\mathrm{CD}^{+}{ }^{+} \mathrm{T}$ cells also contribute to producing IFN- $\gamma$, lysing mycobacteria-infected macrophages, and killing MTB through a granule-dependent mechanism $[37,38]$. Defined by a poor effector function, sustained

Table 5 Frequencies of B cell subsets [Median (IQR)]

\begin{tabular}{lllll}
\hline Subset & HC & HW & TB & TB + HW \\
\hline B cell (\%) & $7.1(4.7-8.9)$ & $7.2(3.5-7.7)$ & $6.6(4.6-7.6)$ & $7.5(5.8-8.4)$ \\
Naïve B cell (\%) & $63.8(42.2-78.5)$ & $71.9(53.4-83.3)$ & $63.4(57.0-74.8)$ & $78.8(71.4-81.1)$ \\
Tissue-like memory B cell (\%) & $5.0(4.1-6.8)$ & $4.7(3.8-6.0)$ & $3.8(2.3-4.9)$ & $5.0(4.2-6.1)$ \\
Activated memory B cell (\%) & $7.8(5.1-10.0)$ & $8.0(7.3-9.0)$ & $7.5(5.2-10.6)$ & $5.0(4.8-8.6)$ \\
Resting memory B cell (\%) & $46.8(29.5-69.1)$ & $65.3(43.2-70.4)$ & $46.0(37.8-54.8)$ & $35.9(33.6-43.4)$ \\
Plasma cell (\%) & $44.6(16.6-66.2)$ & $25.8(18.0-48.1)$ & $44.3(38.2-53.9)$ & $54.7(47.8-60.2)$ \\
\hline
\end{tabular}

IQR: interquartile range; HC: healthy controls without PTB or hookworm infection; HW: patients only with hookworm infection; TB: PTB cases without hookworm infection; TB + HW: PTB cases co-infected with hookworm. 
Table 6 Frequencies of T cell subsets [Median (IQR)]

\begin{tabular}{lllll}
\hline Subset & HC & HW & TB & TB + HW \\
\hline T cell (\%) & $65.5(62.0-73.4)$ & $60.9(58.5-74.3)$ & $65.2(62.4-74.2)$ & $72.2(65.4-73.0)$ \\
Regulatory T cell (\%) & $0.9(0.5-1.1)$ & $0.9(0.2-1.1)$ & $0.7(0.6-0.8)$ & $1.3(0.8-1.5)$ \\
Activated CD4 ${ }^{+}$T cell (\%) & $13.6(8.5-16.4)$ & $10.2(8.9-17.7)$ & $10.4(8.0-12.6)$ & $5.4(3.9-10.8)$ \\
Exhausted CD4 ${ }^{+}$T cell (\%) & $8.4(6.3-11.0)$ & $9.4(7.0-11.7)$ & $7.8(7.0-12.3)$ & $11.4(9.7-14.8)$ \\
Activated CD8 ${ }^{+}$T cell (\%) & $5.4(4.4-8.0)$ & $4.6(4.1-6.1)$ & $4.1(3.5-6.6)$ & $3.6(2.7-5.2)$ \\
Exhausted CD8 ${ }^{+}$T cell (\%) & $9.4(6.7-11.4)$ & $10.8(8.3-13.4)$ & $7.6(5.3-10.4)$ & $11.2(9.6-12.3)$ \\
\hline
\end{tabular}

IQR: interquartile range; HC: healthy controls without PTB or hookworm infection; HW: patients only with hookworm infection; TB: PTB cases without hookworm infection; TB + HW: PTB cases co-infected with hookworm.

expression of inhibitory receptors and a transcriptional state distinct from that of functional effector or memory $\mathrm{T}$ cells, $\mathrm{T}$ cell exhaustion is a state of $\mathrm{T}$ cell dysfunction that arises during many chronic infections and cancer, which means that exhaustion prevents optimal control of infection and tumors [39]. In this study, we found different changes in the cell profile among the study groups: the percentages of activated $\mathrm{CD}^{+}$and $\mathrm{CD} 8^{+} \mathrm{T}$ cells were lower and exhausted $\mathrm{CD} 4^{+}$and $\mathrm{CD}^{+} \mathrm{T}$ cells were higher in the TB $+\mathrm{HW}$ group as compared to the other study groups, which suggests that $\mathrm{T}$ cell activation is weakened and T cell exhaustion is elevated in settings of co-infection of MTB and hookworm. Many studies have shown that hookworm antigens induce cell apoptosis by an intrinsic mitochondrial pathway, and hookworm tissue inhibitor of metalloproteases (Ac-TMP-1)

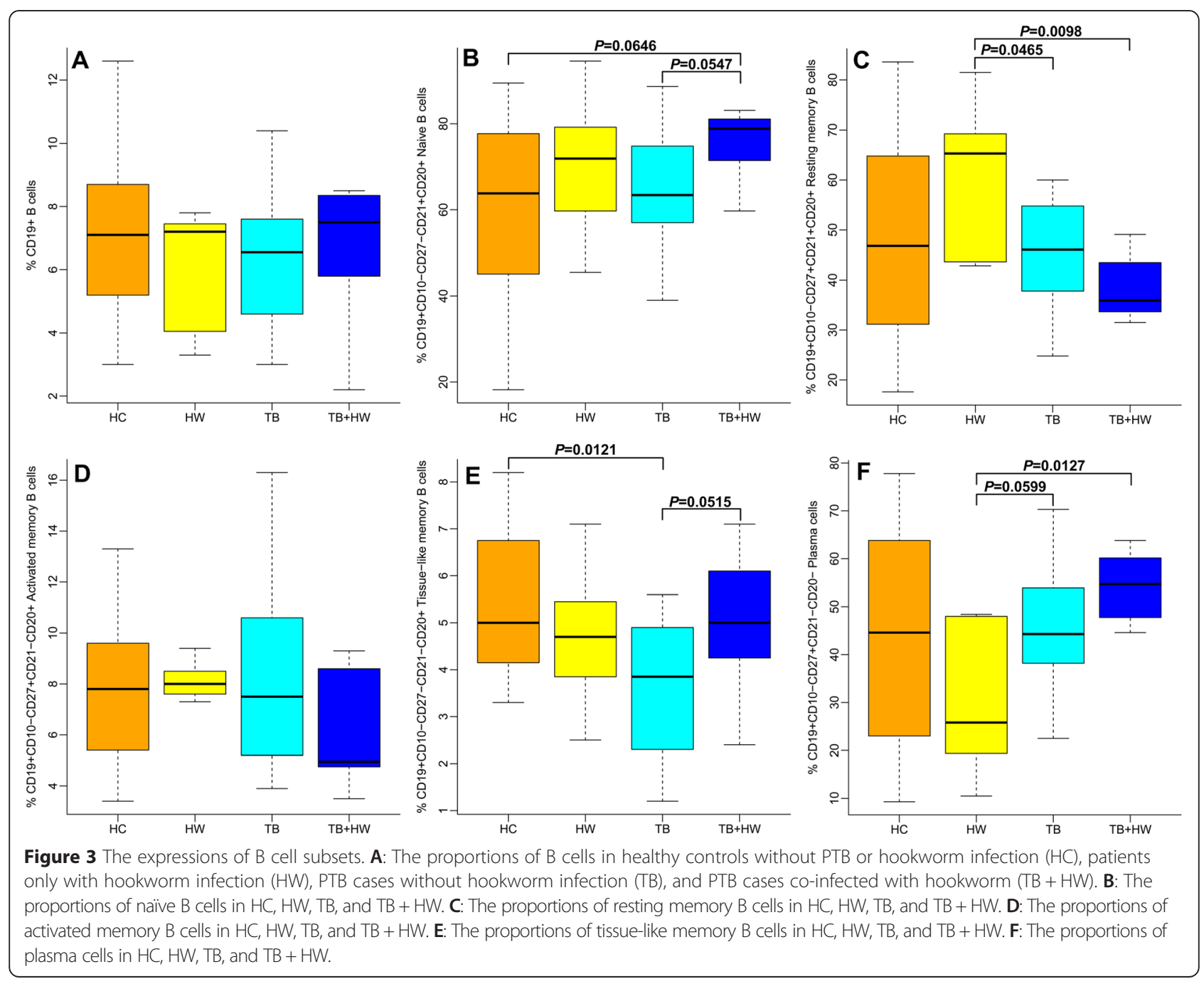




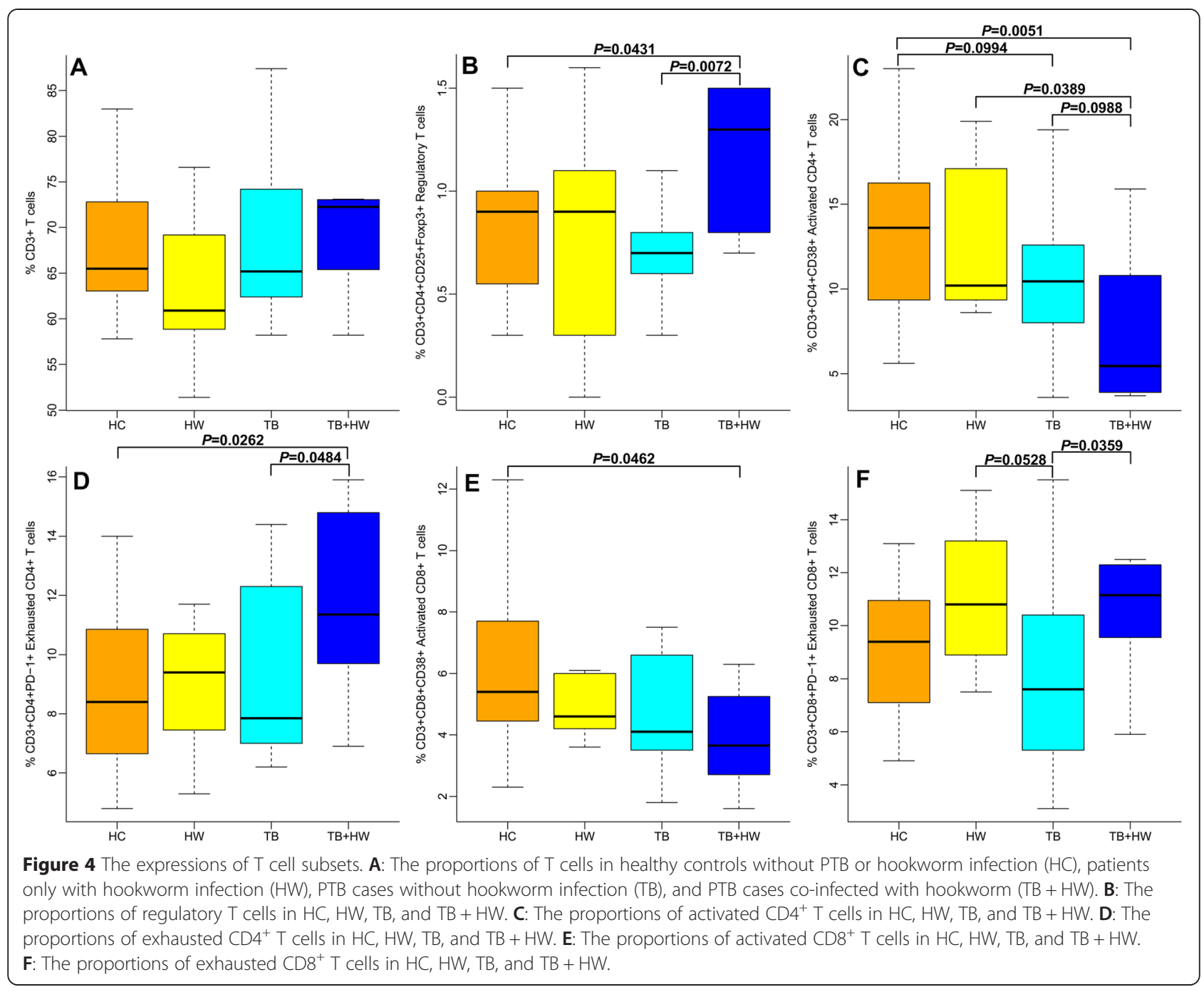

induces generation of suppressor $\mathrm{CD}^{+}$and $\mathrm{CD}^{+} \mathrm{T}$ cells $[40,41]$. This points to the fact that hookworm infection depresses T cell immunity of PTB cases to a certain extent and leads to $\mathrm{T}$ cell dysfunction.

High levels of circulating Treg cells were found in patients with active PTB, compared to individuals with latent infection, with Treg cells inhibiting protective Th1 responses and facilitating mycobacterial replication and tissue damage [42]. Likewise, Treg cells may play an important role in hookworm-induced immunosuppression, contributing to the longevity of hookworm survival in infected people [43]. Moreover, a study demonstrated that Treg cells in human geohelminth (mainly hookworm) infection suppress immune responses to bystander antigen of mycobacteria [44]. In this study, we also found that co-infection of MTB and hookworm raised the proportions of Treg cells compared to MTB infection alone, which means that $\mathrm{T}$ cell-mediated immune response is more suppressed in PTB cases when they are co-infected with hookworm. Some studies indicated Treg cells control the size of the peripheral activated $\mathrm{CD} 4^{+} \mathrm{T}$ cell compartment and suppress cytotoxicity of $\mathrm{CD} 8^{+} \mathrm{T}$ cells $[45,46]$, which is in agreement with findings about Treg cells and T cell exhaustion in this study.

A study found that coincident hookworm infection exerts a profound inhibitory effect on protective Th1 and Th17 responses in latent TB and may predispose toward the development of active TB in humans [47]. Although undergoing anti-TB treatment probably affects the immune responses to MTB infection [48], we also found that $\mathrm{T}$ cell immune response might be more suppressed by co-infection of MTB and hookworm in PTB cases with anti-TB treatment for about four months. This suggests that undergoing anti-TB treatment does not affect coincident hookworm infection inhibiting $\mathrm{T}$ cell immune response to MTB infection.

This study has a number of limitations. First, the sample size was small because participants were only recruited from patients with positive hookworm infection and their controls who all were included in a previous 
cross-sectional survey [17]. Second, participants were elderly because most young adults in the county leave for big cities for employment opportunities, which might have an influence on the immune responses to MTB or hookworm infections [49,50]. Lastly, durations and intensities of hookworm infection that might also have an influence on the immune responses were not evaluated. In view of these limitations, findings of this study should be interpreted carefully when generalized to the larger population and compared with results from other studies.

\section{Conclusion}

Our study found that, in terms of co-infection with MTB and hookworm, for the B cell subsets, naïve B cells, plasma cells, and tissue-like memory B cells had higher proportions and resting memory B cells had lower proportions. For the $\mathrm{T}$ cell subsets, frequencies of Treg cells and exhausted $\mathrm{CD} 4^{+}$and $\mathrm{CD} 8^{+} \mathrm{T}$ cells were higher and frequencies of activated $\mathrm{CD} 4^{+}$and $\mathrm{CD} 8^{+} \mathrm{T}$ cells were lower. The change patterns of the cell profile of circulating lymphocytes were indentified in human co-infection of MTB and hookworm, which might indicate that the humoral and cellular immune responses are more suppressed.

\section{Additional file}

Additional file 1: Multilingual abstracts in the six official working

languages of the United Nations.

\section{Competing interests}

The authors declare that they have no competing interests.

\section{Authors' contributions \\ $X-X L, J-X C, L-X W, X-Y Z$, and $X-N Z$ conceived and designed the study; $X-X$ $L$, J S, S-H C, J-H C, and X-Y Z performed the study; $X-X L$ and J $S$ analyzed the data; $X-X L$ wrote the first draft of the paper; J-X C, L-X W, and $X-Y Z$ provided constructive opinions and suggestions; $X-N Z$ provided strategic advice and assisted with the editing of the paper. All authors read and approved the final version of the paper.}

\section{Acknowledgements}

We are grateful to the staff at the Gushi County Center for Disease Control and Prevention, health workers at township hospitals and village clinics in the Gushi County, and to all participants who contributed their blood samples. This project was supported by the National Science \& Technology Major Program (grant No. 2012ZX10004-220).

\section{Author details}

${ }^{1}$ National Institute of Parasitic Diseases, Chinese Center for Disease Control and Prevention, Key Laboratory of Parasite and Vector Biology, Ministry of Health, WHO Collaborating Centre for Malaria, Schistosomiasis and Filariasis, 207 Rui Jin Er Road, Huangpu District, Shanghai 200025, PR China (PRC). ${ }^{2}$ National Center for Tuberculosis Control and Prevention, Chinese Center for Disease Control and Prevention, Beijing 102206, PR China. ${ }^{3}$ Shanghai Public Health Clinical Center, Key Laboratory of Medical Molecular Virology of Ministry of Education, Institutes of Biomedical Sciences, Fudan University, Shanghai 201508, PR China.
Received: 10 December 2014 Accepted: 20 March 2015

Published online: 04 May 2015

\section{References}

1. World Health Organization. Global tuberculosis report 2012. Geneva, Switzerland: World Health Organization Press; 2012

2. World Health Organization. First WHO report on neglected tropical diseases: working to overcome the global impact of neglected tropical diseases. Geneva, Switzerland: World Health Organization Press; 2010

3. Li XX, Zhou XN. Co-infection of tuberculosis and parasitic diseases in humans: a systematic review. Parasit Vectors. 2013;6:79.

4. Manuel Ramos J, Reyes F, Tesfamariam A. Intestinal parasites in adults admitted to a rural Ethiopian hospital: relationship to tuberculosis and malaria. Scand J Infect Dis. 2006;38:460-2.

5. Range N, Magnussen P, Mugomela A, Malenganisho W, Changalucha J, Temu MM, et al. HIV and parasitic co-infections in tuberculosis patients: a cross-sectional study in Mwanza, Tanzania. Ann Trop Med Parasitol. 2007;101:343-51.

6. Abate E, Belayneh M, Gelaw A, Idh J, Getachew A, Alemu S, et al. The impact of asymptomatic helminth co-infection in patients with newly diagnosed tuberculosis in north-west Ethiopia. PLOS One. 2012;7:e42901.

7. Ferraz JC, Melo FB, Albuquerque MF, Montenegro SM, Abath FG. Immune factors and immunoregulation in tuberculosis. Braz J Med Biol Res. 2006;39:1387-97.

8. Urdahl KB, Shafiani S, Ernst JD. Initiation and regulation of T-cell responses in tuberculosis. Mucosal Immunol. 2011;4:288-93.

9. Kozakiewicz L, Phuah J, Flynn J, Chan J. The role of B cells and humoral immunity in Mycobacterium tuberculosis infection. Adv Exp Med Biol. 2013;783:225-50

10. Maglione PJ, Chan J. How B cells shape the immune response against Mycobacterium tuberculosis. Eur J Immunol. 2009;39:676-86.

11. Eklund D, Welin A, Schon T, Stendahl O, Huygen K, Lerm M. Validation of a medium-throughput method for evaluation of intracellular growth of Mycobacterium tuberculosis. Clin Vaccine Immunol. 2010;17:513-7.

12. Loukas A, Prociv P. Immune responses in hookworm infections, Clin Microbiol Rev. 2001;14:689-703.

13. Onyemelukwe GC, Musa BO. T-lymphocyte subsets in patients with hookworm infection in Zaria, Nigeria. Afr J Med Med Sci. 2001;30:255-9.

14. Olatunde BO, Onyemelukwe GC. Immunosuppression in Nigerians with hookworm infection. Afr J Med Med Sci. 1994;23:221-5.

15. Kalinkovich A, Weisman Z, Greenberg Z, Nahmias J, Eitan S, Stein M, et al. Decreased CD4 and increased CD8 counts with T cell activation is associated with chronic helminth infection. Clin Exp Immunol. 1998;114:414-21.

16. Collins DP. Cytokine and cytokine receptor expression as a biological indicator of immune activation: important considerations in the development of in vitro model systems. J Immunol Methods. 2000;243:125-45.

17. Li XX, Chen JX, Wang LX, Tian LG, Zhang YP, Dong SP, et al. Intestinal parasite co-infection among pulmonary tuberculosis cases without human immunodeficiency virus infection in a rural county in China. Am J Trop Med Hyg. 2014;90:106-13.

18. Disease Control Bureau of the Ministry of Health, Department of Medical Administration of the Ministry of Health, Chinese Center for Disease Control and Prevention. Guidelines for implementing the national tuberculosis control program in China (2008). Beijing, China: Peking Union Medical College Press; 2009.

19. Katz N, Chaves A, Pellegrino J. A simple device for quantitative stool thick-smear technique in schistosomiasis mansoni. Rev Inst Med Trop Sao Paulo. 1972;14:397-400.

20. Demberg T, Brocca-Cofano E, Xiao P, Venzon D, Vargas-Inchaustegui D, Lee EM, et al. Dynamics of memory B-cell populations in blood, lymph nodes, and bone marrow during antiretroviral therapy and envelope boosting in simian immunodeficiency virus SIVmac251-infected rhesus macaques. J Virol. 2012;86:12591-604.

21. Malaspina A, Moir S, Ho J, Wang W, Howell ML, O'Shea MA, et al. Appearance of immature/transitional B cells in HIV-infected individuals with advanced disease: correlation with increased IL-7. Proc Natl Acad Sci U S A. 2006;103:2262-7.

22. Sugalski JM, Rodriguez B, Moir S, Anthony DD. Peripheral blood B cell subset skewing is associated with altered cell cycling and intrinsic resistance 
to apoptosis and reflects a state of immune activation in chronic hepatitis $C$ virus infection. J Immunol. 2010;185:3019-27.

23. Portugal S, Doumtabe D, Traore B, Miller LH, Troye-Blomberg M, Doumbo OK, et al. B cell analysis of ethnic groups in Mali with differential susceptibility to malaria. Malar J. 2012;11:162.

24. Ryan G. T cell signalling: CD3 conformation is crucial for signalling. Nat Rev Immunol. 2010;10:7.

25. Kmieciak M, Gowda M, Graham L, Godder K, Bear HD, Marincola FM, et al. Human T cells express CD25 and Foxp3 upon activation and exhibit effector/memory phenotypes without any regulatory/suppressor function. J Transl Med. 2009;7:89.

26. Sandoval-Montes C, Santos-Argumedo L. CD38 is expressed selectively during the activation of a subset of mature $T$ cells with reduced proliferation but improved potential to produce cytokines. J Leukoc Biol. 2005;77:513-21.

27. Carter L, Fouser LA, Jussif J, Fitz L, Deng B, Wood CR, et al. PD-1:PD-L inhibitory pathway affects both $\mathrm{CD} 4^{+}$and $\mathrm{CD} 8^{+} \mathrm{T}$ cells and is overcome by IL-2. Eur J Immunol. 2002:32:634-43.

28. Yang $H$, Churchill G. Estimating $p$-values in small microarray experiments. Bioinformatics. 2007:23:38-43.

29. Harn DA, McDonald J, Atochina O, Da'dara AA. Modulation of host immune responses by helminth glycans. Immunol Rev. 2009:230:247-57.

30. Prociv P. Pathogenesis of human hookworm infection: insights from a 'new' zoonosis. Chem Immunol. 1997;66:62-98.

31. O'Neal SE, Guimaraes LH, Machado PR, Alcantara L, Morgan DJ, Passos S, et al. Influence of helminth infections on the clinical course of and immune response to Leishmania braziliensis cutaneous leishmaniasis. J Infect Dis. 2007:195:142-8.

32. Ferreira I, Smyth D, Gaze S, Aziz A, Giacomin P, Ruyssers N, et al. Hookworm excretory/secretory products induce interleukin-4 (IL-4) ${ }^{+} \| \mathrm{L}-10^{+} \mathrm{CD} 4^{+} \mathrm{T}$ cell responses and suppress pathology in a mouse model of colitis. Infect Immun. 2013;81:2104-11.

33. Good KL, Bryant VL, Tangye SG. Kinetics of human B cell behavior and amplification of proliferative responses following stimulation with IL-21. J Immunol. 2006;177:5236-47.

34. Moir S, Ho J, Malaspina A, Wang W, DiPoto AC, O'Shea MA, et al. Evidence for HIV-associated B cell exhaustion in a dysfunctional memory B cell compartment in HIV-infected viremic individuals. J Exp Med. 2008;205:1797-805.

35. Good KL, Avery DT, Tangye SG. Resting human memory B cells are intrinsically programmed for enhanced survival and responsiveness to diverse stimuli compared to naive B cells. J Immunol. 2009;182:890-901.

36. Cooper AM. Cell-mediated immune responses in tuberculosis. Annu Rev Immunol. 2009:27:393-422.

37. Green AM, Difazio R, Flynn JL. IFN-gamma from CD4 T cells is essential for host survival and enhances CD8 T cell function during Mycobacterium tuberculosis infection. J Immunol. 2013;190:270-7.

38. Radosevic K, Wieland CW, Rodriguez A, Weverling GJ, Mintardjo R, Gillissen $\mathrm{G}$, et al. Protective immune responses to a recombinant adenovirus type 35 tuberculosis vaccine in two mouse strains: CD4 and CD8 T-cell epitope mapping and role of gamma interferon. Infect Immun. 2007:75:4105-15.

39. Wherry EJ. T cell exhaustion. Nat Immunol. 2011;12:492-9.

40. Gazzinelli-Guimaraes PH, Souza-Fagundes EM, Cancado GG, Martins VG, Dhom-Lemos LC, Ricci ND, et al. Cell apoptosis induced by hookworm antigens: a strategy of immunomodulation. Front Biosci (Elite Ed). 2013;5:662-75

41. Cuellar C, Wu W, Mendez S. The hookworm tissue inhibitor of metalloproteases (Ac-TMP-1) modifies dendritic cell function and induces generation of CD4 and CD8 suppressor T cells. PLoS Negl Trop Dis. 2009;3:e439.

42. Marin ND, Paris SC, Velez VM, Rojas CA, Rojas M, Garcia LF. Regulatory T cell frequency and modulation of IFN-gamma and IL-17 in active and latent tuberculosis. Tuberculosis (Edinb). 2010;90:252-61.

43. Ricci ND, Fiuza JA, Bueno LL, Cancado GG, Gazzinelli-Guimaraes PH, Martins $\mathrm{VG}$, et al. Induction of $\mathrm{CD} 4^{+} \mathrm{CD} 25^{+} \mathrm{FOXP3}^{+}$regulatory T cells during human hookworm infection modulates antigen-mediated lymphocyte proliferation. PLoS Negl Trop Dis. 2011;5:e1383.

44. Wammes $\sqcup$, Hamid F, Wiria AE, de Gier B, Sartono E, Maizels RM et al. Regulatory $T$ cells in human geohelminth infection suppress immune responses to BCG and Plasmodium falciparum. Eur J Immunol. 2010:40:437-42.

45. Annacker O, Burlen-Defranoux O, Pimenta-Araujo R, Cumano A, Bandeira A. Regulatory CD4 T cells control the size of the peripheral activated/memory CD4 T cell compartment. J Immunol. 2000;164:3573-80.
46. Gobel K, Bittner S, Melzer N, Pankratz S, Dreykluft A, Schuhmann MK, et al. $\mathrm{CD}^{+} \mathrm{CD}^{2} 5^{+}$FoxP3 ${ }^{+}$regulatory $T$ cells suppress cytotoxicity of $\mathrm{CD} 8^{+}$ effector T cells: implications for their capacity to limit inflammatory central nervous system damage at the parenchymal level. J Neuroinflammation. 2012;9:41.

47. George PJ, Anuradha R, Kumaran PP, Chandrasekaran V, Nutman TB, Babu S. Modulation of mycobacterial-specific Th1 and Th17 cells in latent tuberculosis by coincident hookworm infection. J Immunol. 2013;190:5161-8.

48. Dominguez J, De Souza-Galvao M, Ruiz-Manzano J, Latorre I, Prat C, Lacoma A, et al. T-cell responses to the Mycobacterium tuberculosis-specific antigens in active tuberculosis patients at the beginning, during, and after antituberculosis treatment. Diagn Microbiol Infect Dis. 2009;63:43-51.

49. Turner J, Frank AA, Brooks JV, Marietta PM, Vesosky B, Orme IM. Tuberculosis in aged gammadelta T cell gene disrupted mice. Exp Gerontol. 2001;36:245-54

50. Sugawara Y, Azuma N, Onodera S, Tsunoka Y, Morimoto M. Th2 immune responses and alternatively activated macrophages (AAMacs) in helminth infection in aged mice. J Vet Med Sci. 2011;73:511-6.

\section{Submit your next manuscript to BioMed Central and take full advantage of:}

- Convenient online submission

- Thorough peer review

- No space constraints or color figure charges

- Immediate publication on acceptance

- Inclusion in PubMed, CAS, Scopus and Google Scholar

- Research which is freely available for redistribution 